\title{
PRODUCTION OF DOCOSAHEXAENOIC ACID (DHA) FROM \\ THRAUSTOCHYTRIUM SP. ATCC 26185 USING DIFFERENTS NITROGEN CONCENTRATIONS
}

\author{
VALCENIR JÚNIOR MENDES FURLAN* \\ MARIA DO CASTELO PAULO** \\ VICTOR WEGNER MAUS*** \\ JÚLIA FERREIRA**** \\ IRINEU BATISTA***** \\ NARCISA MARIA BANDARRA******
}

\begin{abstract}
Polyunsaturated fatty acids (PUFAs) of the type $\omega 3$ and $\omega 6$ play important physiological functions in human organism, since they are components of cell membranes and brain cells; they decrease the levels of triglycerides and can prevent the incidence of coronary heart disease. Various parameters, including concentration of the nitrogen source in the cultivation of oleaginous microorganisms have been reported to be essential in the biosynthesis and accumulation of PUFAs. The objective of this work is to study the effect of different concentrations of total nitrogen (TN) in the production of PUFAs, especially DHA, from Thraustochytrium sp. ATCC 26185. The concentrations of TN evaluated were 2.4 and $0.8 \mathrm{~g} / \mathrm{L}$ (batch) and $0.009 \mathrm{~g} / \mathrm{L}$ (hourly) under fed-batch process. The content of cell biomass, glucose consumption, TN and production of PUFAs was determined. The major composition of the PUFAs in Thraustochytrium sp. ATCC 26185 cell biomass were DPA $\omega 6$ (21-25 \%) and DHA (69$73 \%)$, regardless of the type and time of culture. The maximum cell concentration obtained (30.2 g/L) was using $2.4 \mathrm{~g} / \mathrm{L}$ TN in 168 $\mathrm{h}$ of culture. With this same concentration of TN it was possible to produce the highest concentration of DHA $(1.16 \mathrm{~g} / \mathrm{L})$ in $120 \mathrm{~h}$ of culture, demonstrating that the growth of Thraustochytrium sp. ATCC 26185 and yield of PUFAs are dependent on the concentration TN source available for consumption of this oleaginous microorganism, as well as culture time.
\end{abstract}

KEYWORDS: DOCOSAHEXAENOIC ACID; LIPIDS; NITROGEN SOURCE; POLYUNSATURATED FATTY ACIDS; THRAUSTOCHYTRIDS.

* $\quad$ Engenheiro de Alimentos, Doutor em Engenharia e Ciências de Alimentos, Docente da Universidade Federal do Pampa (UNIPAMPA), Itaqui, RS, Brasil (e-mail: juniorfurlan@unipampa.edu.br).

** Engenheira Biotecnológica, Pesquisadora da Empresa Depsiextracta Biological Technologies-Lda, Taipadas-Canha, Portugal (e-mail: mariacastelo@depsiextracta.com).

*** Engenheiro Ambiental, Doutorando em Ciência do Sistema Terrestre no Instituto Nacional de Pesquisas Espaciais (INPE), Brasil (e-mail: vwmaus1@gmail.com).

**** Técnica em Química, Pesquisadora do National Institute of Biological Resources (INRB/IPMA), Lisboa, Portugal (e-mail: jferreira@ipma.pt).

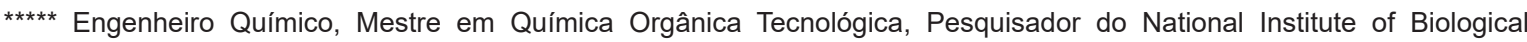
Resources (INRB/IPMA), Lisboa, Portugal (e-mail: irineu@ipma.pt).

****** Química, Doutora em Biotecnologia, Pesquisadora do National Institute of Biological Resources (INRB/IPMA), Lisboa, Portugal (e-mail: narcisa@ipma.pt). 


\section{INTRODUCTION}

Polyunsaturated fatty acids (PUFAs) are among the nutrients of greatest interest because of their beneficial health effects and for their wide application in food and pharmaceutical products (SIJTSMA and SWAAF, 2004). In the human organism they are important for the reproductive, and immune system, in maintenance of cell membranes and the generation of prostaglandins (substances regulating inflammatory processes and blood coagulation). Additionally, PUFAs of $\omega 3$ and $\omega 6$ family reduce levels of LDL (low-density lipoprotein or bad cholesterol) because they modify the composition of cell membranes and lipoproteins, besides inducing increased fecal excretion of cholesterol and bile (RUXTON et al., 2005).

Among the PUFAs, docosahexaenoic acid (DHA, C22:6 w3) and docosapentaenoic acid (DPA, C22:5 w6) may be noted.

Clinical and epidemiological studies have indicated that the DHA is a major component of the phospholipid membrane of the cells of the central nervous system, and is also found in high concentrations in the retina (22 to $33 \%$ of total fatty acids) (DAS and FAMS, 2003; SILVA et al., 2007). Therefore, this fatty acid is critical for brain and visual development of newborns.

Like DHA, the $\omega 6$ (DPA) is important for human health, as it prevents the onset of various diseases, such as cardiovascular accidents (myocardial infarction, thrombosis, atherosclerosis), diabetes, inflammation and rheumatism (arthritis, osteoporosis, asthma) (NAUROTH et al., 2010).

The main commercial sources of these compounds, especially of DHA are oils of marine fish. However, its widespread use is limited due to seasonal variations of fish, marine pollution and the high cost of the process of extraction and purification of this oil (JIANG et al., 2004).

As alternative, heterotrophic microorganisms arise, they do not depend on climatic variation, and can be controlled, resulting in high cellular concentrations, reducing the cost of production (SWAAF et al., 2003). Among these microorganisms, the group Thraustochytrids is highlighted, considered oleaginous, since they can accumulate over $50 \%$ of their weight in the form of lipids, of which more than $25 \%$ can be DHA (RAGHUKUMAR, 2008).

The lipid accumulation in oleaginous microorganisms normally occurs when the medium contains excess carbon source and a limited amount of nitrogen. Thus, when the microorganism multiplies, the nitrogen source is rapidly exhausted, but it continues assimilating the carbon source that is channeled directly to the synthesis of lipids (RATLEDGE and WYNN, 2002). However, culture conditions involving low concentration of nitrogen decrease cell growth thus lower yields are obtained in lipids and DHA (SHENE et al., 2010).

Therefore, this study aimed to investigate the effect of concentration of total nitrogen and culture conditions of the microorganism Thraustochytrium sp. ATCC 26185 for the production of PUFAs, especially DHA.

\section{MATERIALS AND METHODS}

\subsection{MICROORGANISM}

The Thraustochytrium sp. ATCC 26185 strain used in this study was obtained from American Type Culture Collection (Manassas, VA, USA).

\subsection{PREPARATION OF INOCULUM}

Cells from the microorganism Thraustochytrium sp. ATCC 26185 stored at $4{ }^{\circ} \mathrm{C}$ in potato dextrose agar were transferred to $500 \mathrm{~mL}$ flasks containing $100 \mathrm{~mL}$ medium composed ( $\mathrm{g} / \mathrm{L}$ ) of: yeast 
extract (1.0), peptone (1.0) and glucose (5.0) in seawater (1.5\% w/v). The glucose was sterilized separately. Cells were incubated in an orbital shaker (Ika, KS 260B) at $30^{\circ} \mathrm{C}, 150 \mathrm{rpm}$, without light, for $48 \mathrm{~h}$ (FURLAN et al., 2012).

\subsection{CULTURE CONDITIONS}

The cultivations were carried out in bench bioreactor (Sartorius Stedim Biotech, Biostat ${ }^{\circledR}$ Bplus equipped with pressure flow meters and gases and liquids controllers) into the culture vessel borosilicate glass, with a capacity of $5 \mathrm{~L}$, presenting the medium to following composition $(\mathrm{g} / \mathrm{L})$ : $\mathrm{KH}_{2} \mathrm{PO}_{4}$ (1.54), $\mathrm{MgSO}_{4} .7 \mathrm{H}_{2} \mathrm{O}(2.62), \mathrm{NaCl}(0.71)$, glucose (30.0) and different concentrations of total nitrogen (TN): $2.4 \mathrm{~g} / \mathrm{L}\left(6.25 \mathrm{~g} / \mathrm{L}\left(\mathrm{NH}_{4}\right)_{2} \mathrm{SO}_{4}\right.$ and $8.8 \mathrm{~g} / \mathrm{L}$ yeast extract), $0.8 \mathrm{~g} / \mathrm{L}\left(1.89 \mathrm{~g} / \mathrm{L}\left(\mathrm{NH}_{4}\right)_{2} \mathrm{SO}_{4}\right.$ and $3.23 \mathrm{~g} / \mathrm{L}$ yeast extract) in a batch process and $0.009 \mathrm{~g} / \mathrm{L}$ every hour in fed-batch process $(0.021 \mathrm{~g} / \mathrm{L} . \mathrm{h}$ $\left(\mathrm{NH}_{4}\right)_{2} \mathrm{SO}_{4}$ and $0.036 \mathrm{~g} / \mathrm{L}$.h yeast extract). All components were solubilized in $3.15 \mathrm{~L}$ of seawater $(1.2$ $\%, w / v)$.

The sterilization of yeast extract and glucose were performed individually at $121^{\circ} \mathrm{C}$ for $15 \mathrm{~min}$ in an autoclave (Cetorclav, CV-EL-18 L). The bioreactor was sterilized by autoclaving (Ajc, Uniclave $77-127 \mathrm{~L}$ ) for $60 \mathrm{~min}$ and the remaining medium components were sterilized by membrane filtration $(0.22 \mu \mathrm{m}$, Millipore).

The dissolved components (sterilized) were added into the bioreactor with solutions of metal (mg/L): $\mathrm{MnCl}_{2} \cdot 4 \mathrm{H}_{2} \mathrm{O}(3.0), \mathrm{ZnSO}_{4} \cdot 7 \mathrm{H}_{2} \mathrm{O}(3.0), \mathrm{CoCl}_{2} \cdot 6 \mathrm{H}_{2} \mathrm{O}(0.04), \mathrm{Na}_{2} \mathrm{MoO}_{4} \cdot 2 \mathrm{H}_{2} \mathrm{O}(0.04), \mathrm{CuSO}_{4} \cdot 5 \mathrm{H}_{2} \mathrm{O}$ (2.0), $\mathrm{NiSO}_{4} \cdot 6 \mathrm{H}_{2} \mathrm{O}(2.0), \mathrm{FeSO}_{4} \cdot 7 \mathrm{H}_{2} \mathrm{O}(10.0)$ and solution of vitamins (mg/L): Thiamine (9.5) and Calcium pantothenate (3.2) previously sterilized by membrane filtration $(0.22 \mu \mathrm{m}$, Millipore). Finally, was added $350 \mathrm{~mL}$ of inoculum ( $10 \% \mathrm{v} / \mathrm{v}$ with respect to the total volume of culture medium).

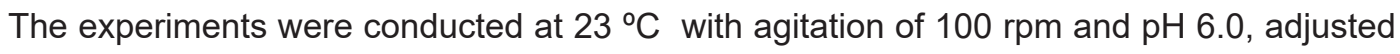
with $\mathrm{NaOH}(4 \mathrm{~N})$. In the first $96 \mathrm{~h}$ of culture the dissolved oxygen concentration in the medium was maintained at $5 \%$ saturation, controlled by aeration (0-2.5 vvm), followed by injection of $0.25 \mathrm{vvm}$ pure oxygen. After this period, injections of air and oxygen were discontinued.

\subsection{DETERMINATION OF THE BIOMASS CONTENT}

The cell concentration was determined according to Min et al. (2012) with modifications at intervals of $24 \mathrm{~h}$, filtering an aliquot of the culture medium on filter paper with glass microfiber (GF/C: $1.2 \mu \mathrm{m}$, Whatman) previously weighed. The biomass in the microfiber layer was washed twice with distilled water and dried at $60^{\circ} \mathrm{C}$ in an oven (Memmert) for $24 \mathrm{~h}$. The biomass content was determined by difference between the initial and final weight.

\subsection{DETERMINATION OF GLUCOSE}

Sugars were measured in the culture supernatant at $24 \mathrm{~h}$ intervals by spectrophotometric method proposed by Miller (1959) using Uv/Vis dual beam absorption spectrophotometer (Ati Unicam Helios, Alpha, UK).

\subsection{DETERMINATION OF TOTAL NITROGEN}

The quantification of the total nitrogen content (defined and complex sources) was performed at intervals of $24 \mathrm{~h}$, in the supernatants of the cultures, according to the procedure by Furlan et al. (2012).

\subsection{DETERMINATION OF FATTY ACIDS PROFILE}

Samples of the culture collected at intervals of 24 hours, were centrifuged (Kubota, 6800) at $8742 \mathrm{~g}$ for $15 \mathrm{~min}$ at $4{ }^{\circ} \mathrm{C}$, and the biomass washed with distilled water and centrifuged again. 
This process was repeated twice. The biomass was frozen at $-20^{\circ} \mathrm{C}$ and dry for $48 \mathrm{~h}$ in a lyophilizer (Heto, Power Dry LL 3000).

Lyophilized cell biomass between 20 and $100 \mathrm{mg}$ was weighed and added to $50 \mu \mathrm{L}$ of internal standard solution $\mathrm{C} 23: 0(50 \mathrm{mg} / \mathrm{mL})$ in order to express the results in $\mathrm{g}$ of fatty acid/g of biomass lyophilized. The methyl esters of fatty acids were prepared by esterification by acid catalysis using the method of Lepage and Roy (1986) modified by Cohen et al. (1988), analyzed by gas chromatograph (Varian, CP 3800) equipped with autosampler, injector and flame ionization detector (FID), both at $250^{\circ} \mathrm{C}$. The separation occurred using a polyethylene glycol capillary column DBWAX (Agilent, $30 \mathrm{~m}$ length, $0.25 \mathrm{~mm}$ internal diameter and $0.25 \mu \mathrm{m}$ thick) heated at $180^{\circ} \mathrm{C}(5 \mathrm{~min})$ gradually increasing every $4{ }^{\circ} \mathrm{C} / \mathrm{min}$ up to $220^{\circ} \mathrm{C}$ (holding for $25 \mathrm{~min}$ ) and in increase gradually $\left(20^{\circ} \mathrm{C} / \mathrm{min}\right.$ ) to $240^{\circ} \mathrm{C}$ (holding for $15 \mathrm{~min}$ ). The methyl esters were identified in the sample by comparison with the retention times of chromatographic patterns Sigma-Aldrich Co. (St. Louis, MO, USA).

Results were subjected to analysis of variance (ANOVA) and significant differences were identified by comparing the average level of $5 \%$ significance. Before performing ANOVA it was necessary to check if the values were normal (Kolmogorov-Smirnov) and their variances were equal to (Cochran) (TRIOLA, 2008).

\section{RESULTS AND DISCUSSION}

\subsection{KINETICS OF GROWTH, GLUCOSE CONSUMPTION AND TOTAL NITROGEN}

Figure 1, 2 and 3 show the average concentrations of the contents of cell biomass, glucose and total nitrogen during the cultivations of Thraustochytrium sp. ATCC 26185.

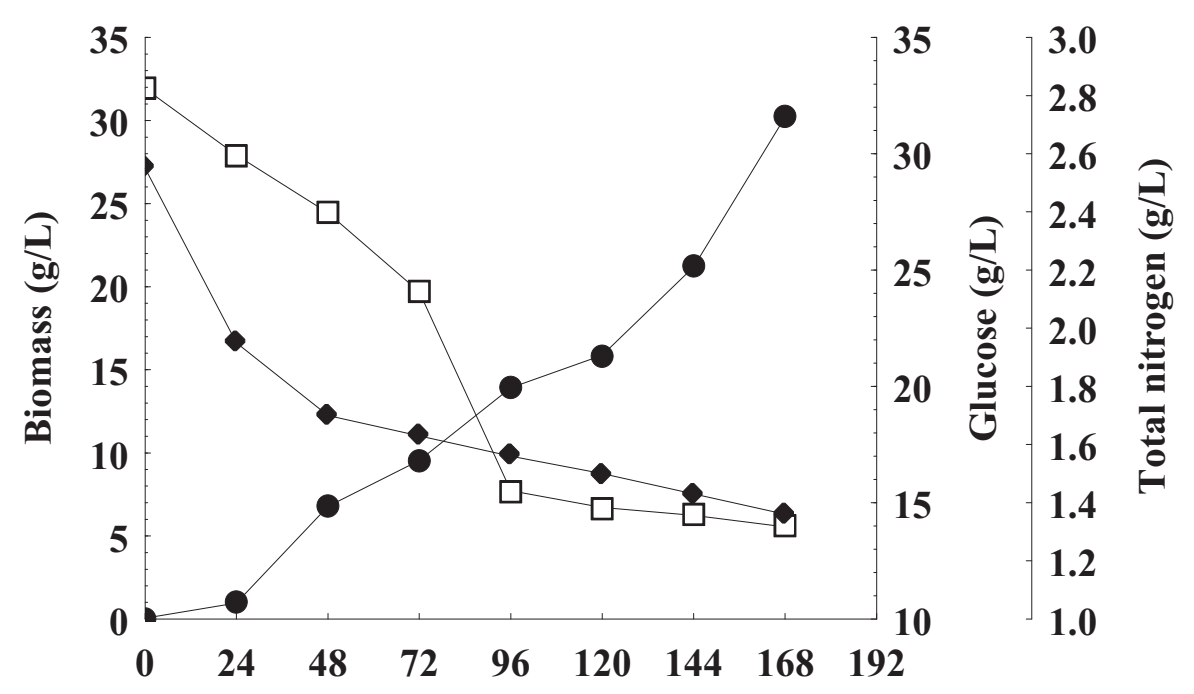

Culture time (h)

FIGURE 1 - CONCENTRATIONS OF BIOMASS, GLUCOSE AND TOTAL NITROGEN DURING THE CULTIVATION OF THRAUSTOCHYTRIUM SP. ATCC 26185, USING 2.4 G/L OF TOTAL NITROGEN

Biomass (g/L) $\square$ Glucose $(\mathrm{g} / \mathrm{L}) \longrightarrow$ Total nitrogen $(\mathrm{g} / \mathrm{L})$ 
The experiment which provided $2.4 \mathrm{~g} / \mathrm{L}$ total nitrogen (Figure 1) showed a maximum specific $\left(\mu_{\max }\right)$ cell growth of $4.29 / \mathrm{h}$, in the early stages of cultivation and a generation time $(\mathrm{tg})$ of $0.16 \mathrm{~h}$. Furthermore, one can observe that the maximum biomass concentration $(30.2 \mathrm{~g} / \mathrm{L})$ was reached after $168 \mathrm{~h}$ of culture, with a productivity of $0.18 \mathrm{~g} / \mathrm{L} . \mathrm{h}$ of cell biomass.

The average consumption of glucose in this assay was $0.11 \mathrm{~g} / \mathrm{L} . \mathrm{h}$ and highest specific speed of consumption of this substrate $(0.67 / \mathrm{h})$ was after the first $24 \mathrm{~h}$ of culture. This experiment also demonstrated that, for every gram of glucose consumed, $1.6 \mathrm{~g}$ of biomass were produced ( $\left.\mathrm{Y}_{\text {Biomass/Glucose }}: 1.6\right)$.

For the supplied nitrogen, the maximum specific consumption rate was $1.34 / \mathrm{h}$ recorded at the baseline, with an average consumption of $0.007 \mathrm{~g} / \mathrm{L}$.h. Featuring a conversion factor of biomass substrate in $25.3\left(\mathrm{Y}_{\text {Biomass/Nitrogen }}\right)$.

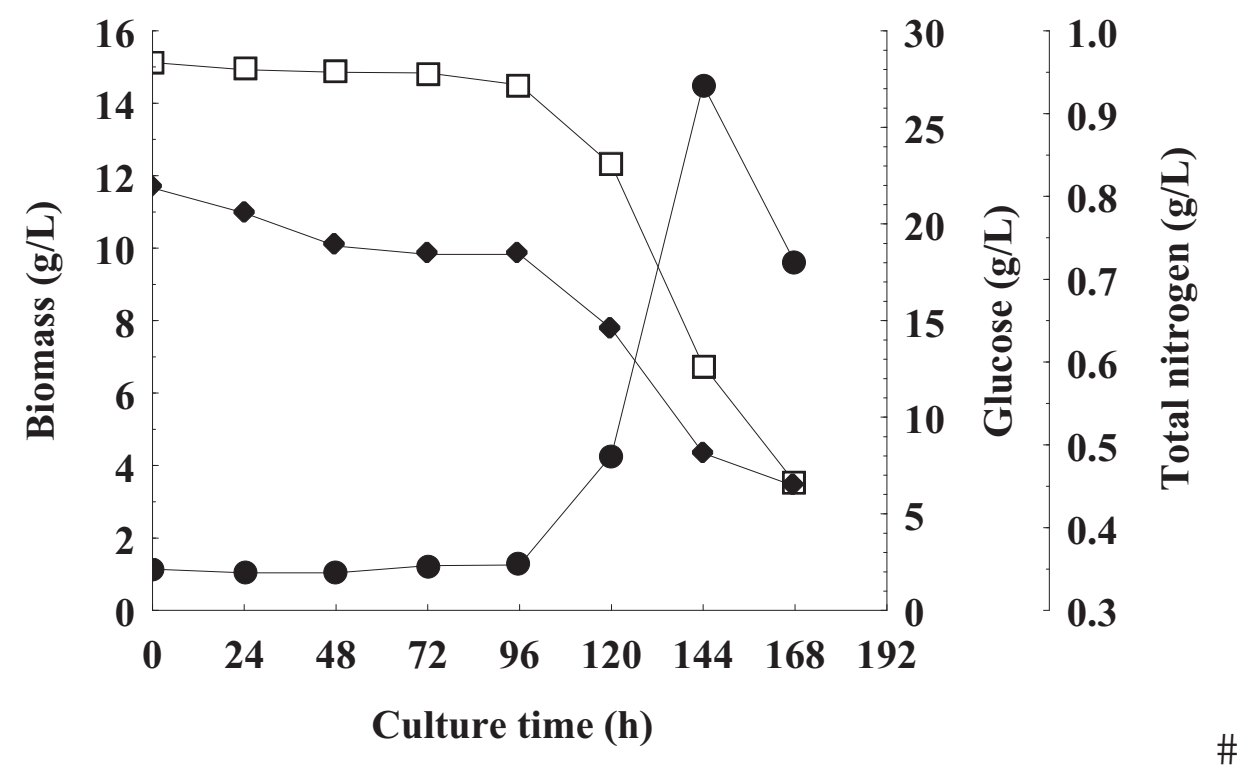

\section{FIGURE 2 - CONCENTRATIONS OF BIOMASS, GLUCOSE AND TOTAL NITROGEN DURING THE CULTIVATION OF THRAUSTOCHYTRIUM SP. ATCC 26185, USING 0.8 G/L OF TOTAL NITROGEN}

Biomass (g/L) $\square$ Glucose (g/L) $\multimap$ Total nitrogen (g/L)

From Figure 2 it can be seen that the highest content of biomass $(14.5 \mathrm{~g} / \mathrm{L})$ was reached after $144 \mathrm{~h}$ of culture, employing $0.8 \mathrm{~g} / \mathrm{L}$ of total nitrogen, with an average productivity $0.11 \mathrm{~g} / \mathrm{L} . \mathrm{h}$ biomass. At this concentration of TN used, the $\mu_{\max }(0.09 / \mathrm{h})$ of cell growth was recorded at $106 \mathrm{~h}$, under these same conditions there was a cell doubling time of $7.4 \mathrm{~h}$.

The maximum specific rate of glucose consumption $(0.07 / \mathrm{h})$ was 101 hours, with an average consumption of $0.13 \mathrm{~g} / \mathrm{L} . \mathrm{h}$ This culture showed a conversion of glucose to biomass $\left(\mathrm{Y}_{\text {Biomass/Glucose }}\right)$ of 0.88 .

At $20 \mathrm{~h}$ the highest specific speed $(0.09 / \mathrm{h})$ of total nitrogen consumption was reached, with average fuel consumption with this substrate of $0.002 \mathrm{~g} / \mathrm{L}$.h. Each gram of nitrogen consumed was converted into $46.4 \mathrm{~g}$ of biomass $\left(\mathrm{Y}_{\text {Biomass/Nitrogen }}\right)$. 


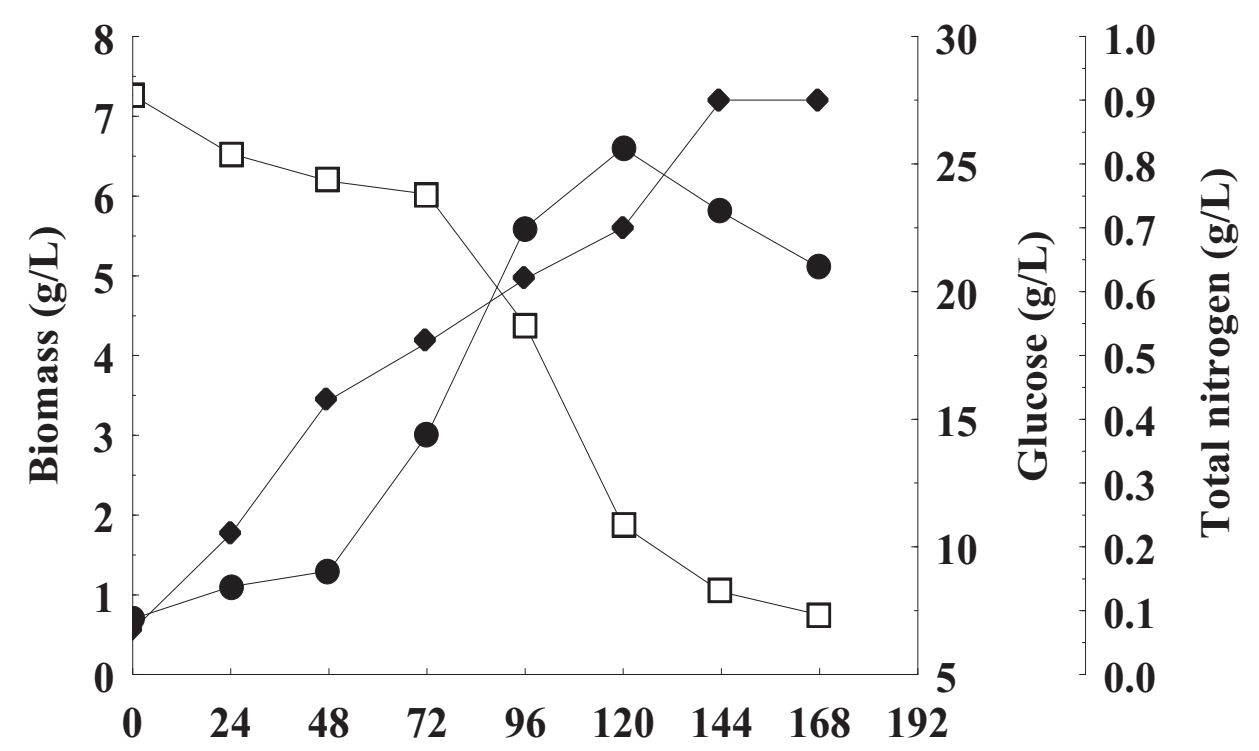

Culture time (h)

\#

\section{FIGURE 3 - CONCENTRATIONS OF BIOMASS, GLUCOSE AND TOTAL NITROGEN DURING THE GROWING THRAUSTOCHYTRIUM SP. ATCC 26185, EMPLOYING FED- BATCH SYSTEMS $0.009 \mathrm{G} / \mathrm{L}$ (HOURLY) OF TOTAL NITROGEN}

Biomass $(g / L) \square$ Glucose $(g / L)-$ Total nitrogen $(g / L)$

Supplying nitrogen under fed-batch process $(0.009 \mathrm{~g} / \mathrm{L} . \mathrm{h} \mathrm{TN})$, it was found that the highest concentration of biomass $(6.6 \mathrm{~g} / \mathrm{L}$ ) was obtained at $120 \mathrm{~h}$ (Figure 3 ), with a maximum productivity of $0.05 \mathrm{~g} / \mathrm{L}$.h of cell biomass. At $55 \mathrm{~h}$ of cultivation maximum specific cell growth $(0.03 / \mathrm{h})$ was observed. Furthermore, the time required for cell replication to occur in this experiment was $24.8 \mathrm{~h}$.

At time 90 hours, the highest specific rate of glucose consumption occurred $(0.06 / \mathrm{h})$ with an average consumption of $0.12 \mathrm{~g} / \mathrm{L}$.h and conversion factor $(0.35)$ glucose into biomass $\left(\mathrm{Y}_{\text {Biomass/Glucose }}\right)$.

Maximum specific consumption of total nitrogen $(0.02 / \mathrm{h})$ was at $6.2 \mathrm{~h}$ of cultivation, the average consumption of this substrate was $0.003 \mathrm{~g} / \mathrm{L}$.h The conversion factor $\left(\mathrm{Y}_{\text {Biomass } / \text { itrogen }}\right.$ : 16.4), indicated that for each gram of nitrogen consumed $16.4 \mathrm{~g}$ of biomass was produced.

The experiment which provided $2.4 \mathrm{~g} / \mathrm{L}$ of total nitrogen to the culture medium, obtained the maximum cell concentration ( $30.2 \mathrm{~g} / \mathrm{L})$, as the strain of Thraustochytrium sp. 26185 registered in the cultivation speeds specific substrate consumption and the shortest time required for cell duplication (tg: $0.16 \mathrm{~h}$ ). The higher consumption of total nitrogen $(0.007 \mathrm{~g} / \mathrm{L} . \mathrm{h})$ observed in this condition gave better cell productivity $(0.18 \mathrm{~g} / \mathrm{L} . \mathrm{h})$ when compared to other experiments, since nitrogen promotes the synthesis of nucleic acids and proteins and consequently the cell division (BURJA et al., 2006).

Ganuza et al. (2008) evaluated the use of ammonium tartrate as nitrogen source in the culture medium of Schizochytrium sp. and found that the microorganism grew to $23.8 \mathrm{~g} / \mathrm{L}$ in 48 hours, providing $1.85 \mathrm{~g} / \mathrm{L} \mathrm{TN}$.

In the study by Chen et al. (2010) the maximum cell concentration $(9.27 \mathrm{~g} / \mathrm{L})$ was obtained when cultured Aurantiochytrium sp. BR-MP4-A1 with $2.4 \mathrm{~g} / \mathrm{L}$ of TN.

Min et al. (2012) studied the effect of cultivation conditions on the growth of Thraustochytrium roseum ATCC 34303 and reached a maximum cellular biomass content of $7.9 \mathrm{~g} / \mathrm{L}$, employing glucose concentration of $30 \mathrm{~g} / \mathrm{L}$ and $0.6 \mathrm{~g} / \mathrm{L}$ total nitrogen (yeast extract and peptone). 
From Figure 2 and 3 it is noted that this microorganism under the conditions studied, reached maximum values of cell biomass in the times of 144 and $120 \mathrm{~h}$ of culture, respectively, with subsequent decrease. This decrease in biomass content can be related to the inhibition of this microorganism caused by the formation of acidic products during cultivation, since McCormick (1995) reported that environmental conditions are becoming increasingly unsuitable for the cells to survive over time. Another reason would be the cell death caused by the deficiency of a nutrient medium. Low concentrations of glucose and TN evidenced in these experiments can be one of the reasons for this cell decline, since these values at $168 \mathrm{~h}$ of culture (Figure 2 and 3 ) were approximately half of those that were quantified in the experiment which used $2.4 \mathrm{~g} / \mathrm{L} \mathrm{TN}$ at the same time (Figure 1).

In Figure 3, one can also see an accumulation of TN along the cultivation, since the amount delivered (fed-batch) was greater than the amount required for the cell development and maintenance.

The fed-batch cultivation consumed approximately the same amounts of substrate $(0.12$ $\mathrm{g} / \mathrm{L} . \mathrm{h}$ of glucose and $0.003 \mathrm{~g} / \mathrm{L} . \mathrm{h}$ nitrogen) used as the cultivation that used $0.8 \mathrm{~g} / \mathrm{L}$ of total nitrogen $(0.13 \mathrm{~g} / \mathrm{L} . \mathrm{h}$ glucose and $0.002 \mathrm{~g} / \mathrm{L} . \mathrm{h}$ nitrogen). However, its conversion efficiency in cellular biomass $(0.05 \mathrm{~g} / \mathrm{L} . \mathrm{h})$ was not observed as in the experiment with $0.8 \mathrm{~g} / \mathrm{L} \mathrm{TN}(0.11 \mathrm{~g} / \mathrm{L} . \mathrm{h})$. Possibly this occurred because part of nutrients have been used only for cellular maintenance and not for favoring cell multiplication. It is noteworthy that the time required for cell replication (tg: $24.8 \mathrm{~h}$ ) in the experiment under fed-batch process was superior to $7.4 \mathrm{~h}(\mathrm{tg})$ which used the cultivation $0.8 \mathrm{~g} / \mathrm{L} \mathrm{TN}$.

\subsection{FATTY ACID PROFILE}

Figure 4 shows the average values of the contents of PUFAs versus time of cultivation of Thraustochytrium sp. ATCC 26185.

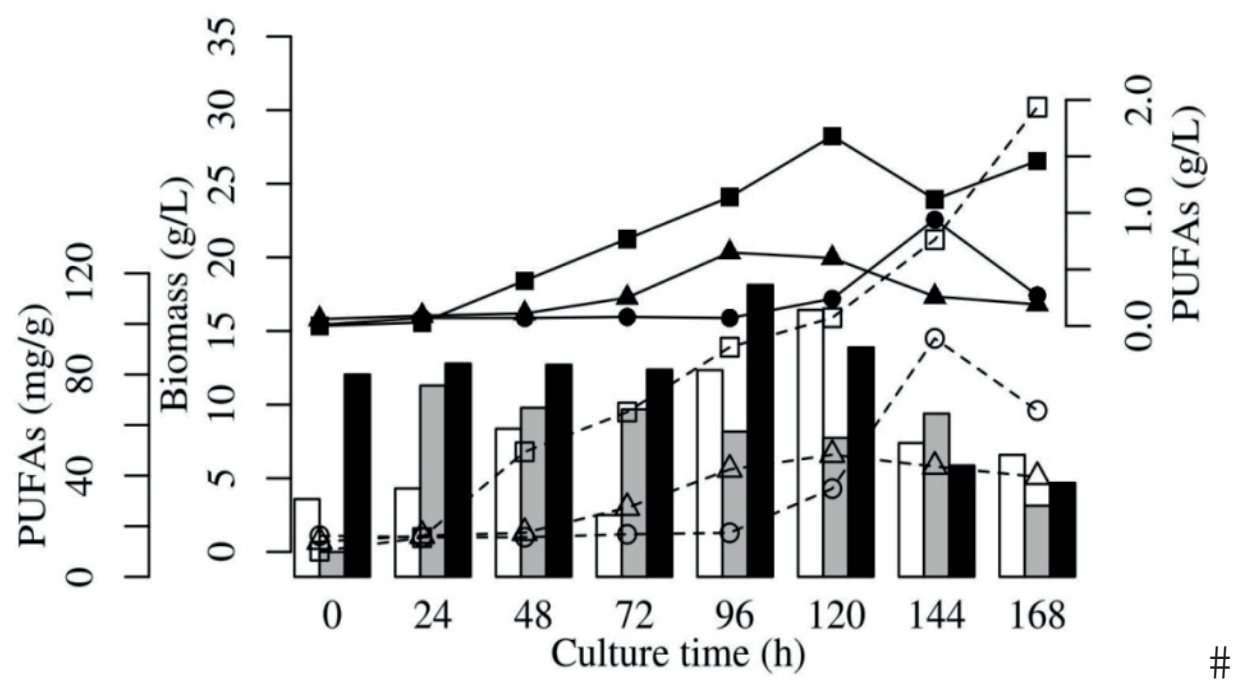

FIGURE 4 - PUFAS CONTENT IN THE BIOMASS OF THRAUSTOCHYTRIUM SP. ATCC 26185. TN: TOTAL NITROGEN

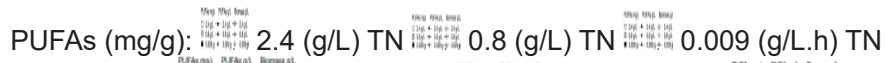

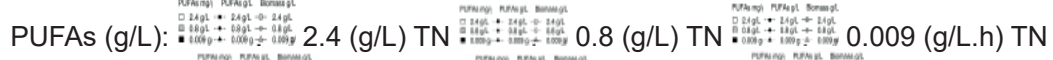

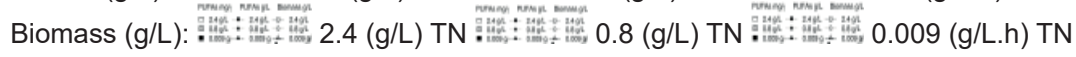


From the results of PUFAs ( $\mathrm{g} / \mathrm{L}$ ) it was possible to apply ANOVA, followed by the comparison test between means (Tukey) at $5 \%$ significance level, which we can conclude that there was significant difference between the times of cultivation in the three nitrogen concentrations studied, except in times of 96 and $144 \mathrm{~h}$ for the cultivation which used $2.4 \mathrm{~g} / \mathrm{L}$ of total nitrogen and from 24 to $96 \mathrm{~h}$ for the experiment that used $0.8 \mathrm{~g} / \mathrm{L}$ of TN. The highest yield of PUFAs $(1.68 \mathrm{~g} / \mathrm{L})$ was observed in the experiment that provided $2.4 \mathrm{~g} / \mathrm{L}$ of total nitrogen after $120 \mathrm{~h}$ of cultivation. In the cultivation with $0.8 \mathrm{~g} / \mathrm{L} \mathrm{TN}$, the greatest amount of PUFAs $(0.94 \mathrm{~g} / \mathrm{L})$ was obtained at $144 \mathrm{~h}$; while under cultivation in the fed-batch process was at $96 \mathrm{~h}$ that the maximum production of PUFAs $(0.65 \mathrm{~g} / \mathrm{L})$ was recorded (Figure 4).

The Figure 5 shows the fatty acid profile for each experiment in periods where the highest yields were achieved in PUFAs ( $\mathrm{g} / \mathrm{L})$.

0.009 (g/L.h)

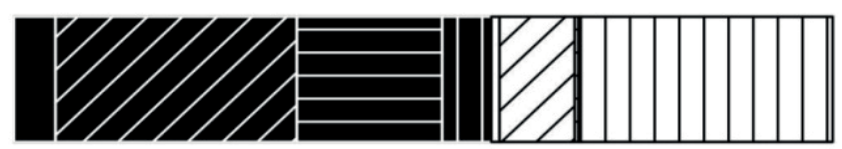

$0.8(\mathrm{~g} / \mathrm{L})$

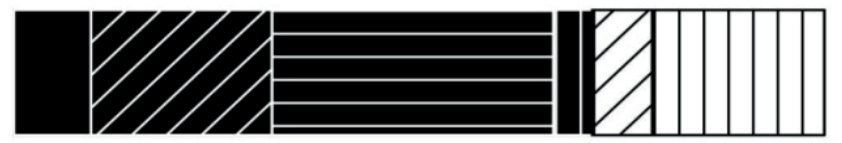

$2.4(\mathrm{~g} / \mathrm{L})$
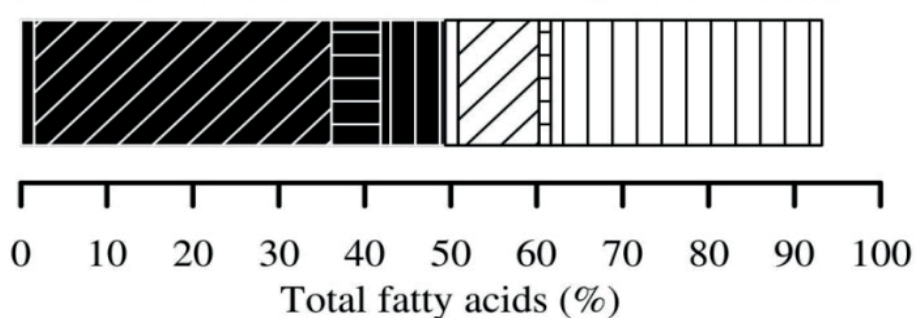

FIGURE 5 - COMPOSITION OF FATTY ACIDS OF CELL BIOMASS OF THRAUSTOCHYTRIUM SP. ATCC 26185 DURING 120 H (2.4 G/L TOTAL NITROGEN), 144 H (0.8 G/L TOTAL NITROGEN) AND 96 H (0.009 G/L.H TOTAL NITROGEN)

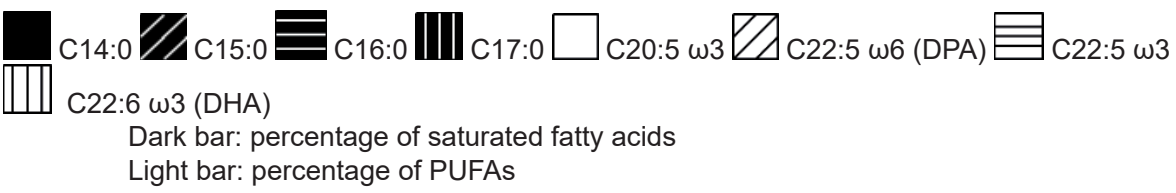

In the experiment which utilized $2.4 \mathrm{~g} / \mathrm{L}$ of nitrogen (120 h of culture), $10.5 \%(\mathrm{w} / \mathrm{w})$ of cell biomass consisted of PUFAs, with $21 \%$ of these being DPA $\omega 6$ (Figure 5 ) that is $2.2 \%$ of the total biomass $(0.35 \mathrm{~g} / \mathrm{L})$. It can also be seen that $69 \%$ of PUFAs were DHA (Figure 5 ), that is $7.3 \%$ of biomass $(1.16 \mathrm{~g} / \mathrm{L})$.

In the cultivation that employed $0.8 \mathrm{~g} / \mathrm{L}$ of TN at point $144 \mathrm{~h}, 6.5 \%(\mathrm{w} / \mathrm{w})$ of cell biomass was composed of PUFAs, and $25 \%$ was DPA $\omega 6$ (Figure 5$)$ that is $1.6 \%$ biomass content $(0.23$ $\mathrm{g} / \mathrm{L}$ ). One can also observe that $73 \%$ of DHA was PUFAs (Figure 5 ) or $4.7 \%$ of the total biomass (0.68 g/L).

While in culture which provided $0.009 \mathrm{~g} / \mathrm{L}$.h nitrogen (96 h point), $11.6 \%(\mathrm{w} / \mathrm{w})$ of the biomass consisted of PUFAs, $21 \%$ of these were DPA $\omega 6$ (Figure 5 ) or $2.5 \%$ of the total biomass $(0.14 \mathrm{~g} / \mathrm{L}$ ). It can also be seen that $73 \%$ of DHA was PUFAs (Figure 5 ) or $8.4 \%$ of the total biomass $(0.47 \mathrm{~g} / \mathrm{L})$. 
In this study, among the fatty acids a high content of C15:0 (21-35\%) and C16:0 (5-33\%) which are saturated was found (Figure 5). The presence of fatty acid C15:0 in lipids produced by strains of Thraustochytrids, has been reported by other authors (KAMLANGDEE and FAN, 2003; CHANG et al., 2011). These results show the importance of propionate in the metabolic pathway of this microorganism (VLAEMINCK et al., 2006).

DHA was the predominant PUFA, ranging from 20 to $31.5 \%$ of total fatty acids (Figure 5). Similar results were observed in the study by Scott et al. (2011), where the content of C16:0 was 33 $\%$ and DHA $36 \%$, relative to the total fatty acids, using Thraustochytrium sp. ONC-T18 after 5 days of cultivation. These authors also observed that DHA and DPA $\omega 6$ were the main PUFAs detected, as in the present study (Figure 5).

Observing the major fatty acids which form the PUFAs biomass, irrespective of the type and culture time, distribution of DPA $\omega 6$ (21-25\%) was approximated, as well as that of DHA (69-73\%), with little variation (Figure 5).

The fed-batch process experiment accumulated greater amounts of PUFAs (11.6\%) in relation to cell weight, than other cultivations. This accumulation can be due to the low content of nitrogen supplied over time. According to Shene et al. (2010), a limited amount of substrate favors the accumulation of lipids by oleaginous microorganisms. Ganuza and Izquierdo (2007) observed that the greatest accumulation of fatty acids in the biomass of Schizochytrium sp. G13/2S were between $28-30 \%(w / w)$, employing low concentrations of monosodium glutamate $(2-4 \mathrm{~g} / \mathrm{L})$ as nitrogen source and when this concentration was increased to $6 \mathrm{~g} / \mathrm{L}$, production of fatty acids decreased, because the cells accumulated nitrogen compounds.

However, cultivation in fed-batch process had lower DHA $(0.47 \mathrm{~g} / \mathrm{L})$ and DPA $\omega 6(0.14 \mathrm{~g} / \mathrm{L})$ yields, due to lower cell concentration $(5.6 \mathrm{~g} / \mathrm{L})$ obtained when compared to that of cultivations which

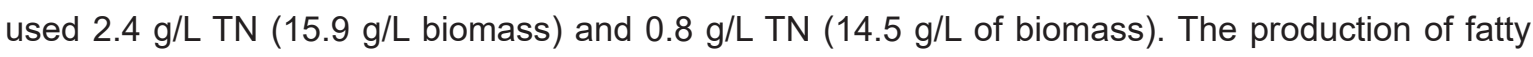
acids such as DPA $\omega 6$ and DHA is dependent on accumulation of PUFAs, as well as the accumulation of lipid in the biomass. Thus, the yield of fatty acids is also related to the cellular concentration of microorganism at a given time. According to Shene et al. (2010) cultivation conditions involving low concentrations of TN, decrease cell growth, thus lower yields of lipid and DHA are obtained. This may be a cause of decrease of the content of PUFAs in final stage of cultivation of the strain of Thraustochytrium sp. ATCC 26185 seen in Figure 4.

Burja et al. (2006) evaluated different concentrations of nitrogen in the culture medium of Thraustochytrium sp. ONC-T18, and found that at the highest concentration of TN studied (1.24 g/L) $1.56 \mathrm{~g} / \mathrm{L}$ of DHA was obtained, $6.7 \%$ (w/w) of cell biomass.

\section{CONCLUSIONS}

Using $2.4 \mathrm{~g} / \mathrm{L}$ of total nitrogen reached the highest content of cell biomass $(30.2 \mathrm{~g} / \mathrm{L})$ at 168 $\mathrm{h}$ of cultivation.

The majority of PUFAs found in biomass of Thraustochytrium sp. ATCC 26185 were DPA $\omega 6(21-25 \%)$ and DHA (69-73\%), whose percentages did not show large variations with different growth conditions studied.

The highest yield of PUFAs (1.68 g/L) obtained from Thraustochytrium sp. ATCC 26185 was after $120 \mathrm{~h}$ of cultivation, giving $2.4 \mathrm{~g} / \mathrm{L}$ of total nitrogen in a batch process. Under the same conditions, the highest concentrations of DHA $(1.16 \mathrm{~g} / \mathrm{L})$ and DPA $\omega 6(0.35 \mathrm{~g} / \mathrm{L})$ were recorded.

This study showed that the growth of Thraustochytrium sp. ATCC 26185 and production of PUFAs, especially DHA are dependent on the concentration of the nitrogen source available for the consumption of this oleaginous microorganism, as well as cultivation time. Therefore, parameters such as medium composition and environmental factors should be considered to increase production of PUFAs. 


\section{PRODUÇÃO DE ÁCIDO DOCOSAHEXAENÓICO (DHA) POR THRAUSTOCHYTRIUM SP. ATCC 26185 UTILIZANDO DIFERENTES CONCENTRAÇÕES DE NITROGÊNIO}

\section{RESUMO}

Os ácidos graxos poliinsaturados (PUFAs) dos tipos $\omega 3$ e $\omega 6$ desempenham funções fisiológicas importantes ao organismo humano, uma vez que são componentes das membranas celulares e de células cerebrais, diminuem os níveis de triglicerídios e podem prevenir as incidências de doenças coronarianas. Diversos parâmetros, incluindo a concentração da fonte de nitrogênio no cultivo de micro-organismos oleaginosos, têm sido relatados por serem fundamentais na biossíntese e no acúmulo de PUFAs. Este trabalho teve como objetivo, estudar o efeito de diferentes concentrações de nitrogênio total (NT) para a produção de PUFAs, especialmente DHA, a partir de Thraustochytrium sp. ATCC 26185. As concentrações de NT avaliadas foram: 2,4 e 0,8 $\mathrm{g} / \mathrm{L}$ (processo descontínuo) e 0,009 $\mathrm{g} / \mathrm{L}$ (a cada hora) sob processo descontínuo alimentado. Foram determinados os conteúdos de biomassa celular, consumo de glicose, NT e a produção de PUFAs. A composição majoritária dos PUFAs na biomassa celular de Thraustochytrium sp. ATCC 26185 foram DPA $\omega 6$ (21-25 \%) e DHA (69-73 \%), independente do tipo e tempo de cultivo. A concentração celular máxima obtida (30,2 g/L) foi utilizando $2,4 \mathrm{~g} / \mathrm{L}$ de NT em $168 \mathrm{~h}$ de cultivo, com esta mesma concentração de NT foi possível produzir a maior concentração de DHA (1,16 g/L) em $120 \mathrm{~h}$ de cultivo, demonstrando que o crescimento de Thraustochytrium sp. ATCC 26185 e o rendimento em PUFAs são dependentes da concentração da fonte de NT disponível para o consumo deste microorganismo oleaginoso, assim como do tempo de cultivo.

PALAVRAS-CHAVE: ÁCIDO DOCOSAHEXAENÓICO; LIPÍDIOS; FONTE DE NITROGÊNIO; ÁCIDOS GRAXOS POLIINSATURADOS; THRAUSTOCHYTRIDS.

\section{ACKNOWLEDGMENTS}

This work was supported by Coordination for Improvement of Higher Education Personnel of Brazil (CAPES) and developed at the National Institute of Biological Resources, I.P. (INRB/IPMA) in Lisbon, PT, through a scholarship granted to the first author by the Doctoral in the country with Internship Abroad Program-PDEE (Proc. № 6906/10-9). The authors also thank Project ALGAENE and Depsiextracta Biological Technologies, Lda.

\section{REFERENCES}

1 BURJA, A.M.; RADIANINGTYAS, H.; WINDUST, A.; BARROW, C.J. Isolation and polyunsaturated fatty acid producing Thraustochytrium species: screening of strains and optimization of omega-3 production. Applied Microbiology and Biotechnology, v. 72, p. 1161-1169, 2006.

2 CHANG, K.J.L.; MANSOUR, M.P.; DUNSTAN, G.A.; BLACKBURN, S.I.; $\quad$ KOUTOULIS, $\quad$ A.; $\quad$ NICHOLS, P.D. Odd-chain polyunsaturated fatty acids in Thraustochytrids. Phytochemistry, v. 72, p. 1460-1465, 2011.

3 CHEN, G.Q.; FAN, K.W.; LU, F.P.; LI, Q.; AKI, T.; CHEN, F.; JIANG, Y. Optimization of nitrogen source for enhanced production of squalene from thraustochytrid Aurantiochytrium sp. New Biotechnology, v. 27, p. 382-389, 2010.

4 COHEN, Z.; VONSHAK, A.; RICHMOND, A. Effect of environmental conditions on fatty acid composition of the red algae Porphyridium cruentum: correlation to growth rate. Journal of Phycology, v. 24, p. 328-332, 1988.

5 DAS, U.N.; FAMS, M.D. Long-chain polyunsaturated fatty acids in the growth and development of the brain and memory. Nutrition, v. 19, p. 62-65, 2003.

6 FURLAN, V.J.M.; PAULO, M.C.; BATISTA, I.; BANDARRA, N.M.; SANTO, M.L.E.; concentration of glucose in the docosahexaenoic acid (DHA) production by Thraustochytrium sp. ATCC 26185. 
7 GANUZA, E.; ANDERSON, A.J.; RATLEDGE, C. High-cell-density cultivation of ammonium/pH-auxostat fed-batch system. Biotechnology

Letters, v. 30, p. 1559-1564, 2008.

8 GANUZA, E.; IZQUIERDO, M.S. Lipid accumulation in Schizochytrium G13/2S produced in continuous culture. Applied Microbiology and Biotechnology, v. 76, p. 985-990, 2007.

9 JIANG, Y.; FAN, K.W.; WONG, R.T.; CHEN, F. Fatty acid composition and squalene content of the marine microalga Schizochytrium mangrovei. Journal of Agricultural and Food Chemistry, v. 52, n. 5, p. 1196-1200, 2004.

10 KAMLANGDEE, N.; FAN, K.W. Polyunsaturated fatty acids production by $\quad$ Schizochytrium sp. isolated from mangrove. Songklanakarin Journal of Science and Technology, v. 25, p. 643-650, 2003.

11 LEPAGE, G.; ROY, C.C. Direct transesterification of all classes of lipids in a one-step reaction. Journal of Lipid Research, v. 27, p. 114-119, 1986.

12 MCCORMICK, T.S.R. The essentials of microbiology. Research and Education $42-44 \mathrm{p}$.

Association, Piscataway, 1995,

13 MILLER, G.L. Use of dinitrosalicylic acid reagent for determination of reducing sugar. Analytical Chemistry, v. 31, n. 3, p. 426-428, 1959.

14 MIN, K.H.; LEE, H.H.; ANBU, P.; CHAULAGAIN, B.P.; HUR, B.K. The effects of culture conditions on the growth property and docosahexaenoic acid production from Thraustochytrium aureum ATCC 34304. Korean Journal Chemical Engineer, $\quad$ v. 29, p. 1211-1215, 2012.

15 NAUROTH, J.M.; LIU, Y.C.; ELSWYK, M.V.; BELL, R.; HALL, E.B.; CHUNG, G.; $\quad$ ARTERBURN, $\quad$ L.M. Docosahexaenoic acid (DHA) and docosapentaenoic acid (DPA $n-6)$ algal oils reduce inflammatory mediators in human peripheral mononuclear cells $\quad$ in vitro and paw edema in vivo. Lipids, v. 45, p. 375-384, 2010.

16 RAGHUKUMAR, S. Thraustochytrid marine protists: production of PUFAs and other emerging technologies. Marine Biotechnology, v. 10, p. 631-640, 2008.

17 RATLEDGE, C.; WYNN, J. P. The biochemistry and molecular biology of lipid microorganisms. Advances in Applied Microbiology, v. $\quad$ 51, p. 1-51, 2002.

18 RUXTON, C.H.S.; CALDER, P.C.; REED, S.C.; SIMPSON, M.J.A. The impact of polyunsaturated fatty acids on human health. Nutrition Research Reviews,

accumulation in oleaginous$$
\begin{aligned}
& \text { long- chain } \quad \text { w3 } \\
& \text { v. 18, p. 113-129, 2005. }
\end{aligned}
$$

19 SCOTT, S.D.; ARMENTA, R.E.; BERRYMAN, K.T.; NORMAN, A.W. Use of raw glycerol to produce oil rich in polyunsaturated fatty acids by a thraustochytrid. Enzyme and Microbial Technology, v. 48, p. 267-272, 2011.

20 SHENE, C.; LEYTON, A.; ESPARZA, Y.; FLORES, L.; QUILODRÁN, B.; HINZPETER, I.; RUBILAR, M. Microbial oils and fatty acids: effect of carbon source on docosahexaenoic acid (C22:6 n-3, DHA) production by Thraustochytrid strains. Journal of Soil Science and Plant Nutrition, v. 10, n. 3, p. 207-216, 2010.

21 SIJTSMA, L.; SWAAF DE M.E. Biotechnological production and applications of the $\omega-3$ polyunsaturated fatty acid docosahexaenoic acid. Applied Microbiology and Biotechnology, v. 64, p. 146-153, 2004.

22 SILVA, D.R.B.; MIRANDA-JÚNIOR, P.F.; SOARES, E.A. A importância dos ácidos graxos poliinsaturados de cadeia longa na gestação e lactação. Revista Brasileira de Saúde Materno Infantil, v. 7, n. 2, p. 123-133, 2007.

23 SWAAF, M.E.; SIJTSMA, L.; PRONK, J.T. High-cell-density fedbatch cultivation of the docosahexaenoic-acid producing marine alga Crypthecodinium cohnii. Biotechnology and Bioengineering, v. 81, p. 666-672, 2003.

24 TRIOLA, M.F. Introdução à estatística. 10ª ed. Ltc, Rio de Janeiro, 2008. 696p.

25 VLAEMINCK, B.; FIEVEZ, V.; CABRITA, A.R.J.; FONSECA, A.J.M.; DEWHURST, $\quad$ R. J. $\quad$ Factors affecting oddand branched-chain fatty acids in milk: A review. Animal Feed Science and Technology, v. 131, p. 389-417, 2006. 